\title{
PERANCANGAN SISTEM INFORMASI AKUNTANSI PERHITUNGAN HARGA POKOK PRODUKSI KONVEKSI MUZAMMIL KENDAL MENGGUNAKAN METODE VARIABLE COSTING
}

\author{
Bagus Sudirman', Ahmad Ashifuddin Aqham², Muhamad Sidik ${ }^{3}$ \\ ${ }^{1}$ Jurusan Teknik Informatika Fakultas Komputer \& Bisnis Universitas STEKOM Semarang \\ ${ }^{2}$ Jurusan Komputerisasi Akuntansi Fakultas Ilmu Terapan Universitas STEKOM Semarang \\ ${ }^{3}$ Jurusan Teknik Informatika Fakultas Komputer \& Bisnis Universitas STEKOM Semarang \\ ${ }^{1}$ bagus@stekom.ac.id, ${ }^{2}$ ashif@stekom.ac.id,${ }^{3}$ sidik@stekom.ac.id
}

\begin{abstract}
Abstrak
Konveksi Muzammil adalah sebuah perusahaan yang bergerak di bidang produsen celana jeans, yang berlokasi di desa Cepoko Mulyo Kendal Jawa Tengah yang didirikan sejak tahun 1998. Perhitungan biaya produksi dan harga jual Konveksi Muzammil Cepoko Mulyo masih menggunakan perhitungan secara konvensional. Padahal era sekarang diperlukan manajemen strategi yang lebih baik demi bersaing secara kompetitif di dunia industri. Oleh karena itu diperlukan sebuah sistem informasi yang sesuai guna mendukung aktifitas bisnis Konveksi Muzammil dalam melakukan pengelompokan biaya, data dan pembuatan sistem laporan. Salah satu cara yang bisa dilakukan adalah memanfaatkan sistem informasi berbasis teknologi informasi untuk memudahkan proses penghitungan biaya produksi dan meningkatkan ketepatan dalam memanajemen keuangan secara keseluruhan. Penelitian ini merancang sebuah Sistem Informasi Akuntansi Perhitungan Harga Pokok Produksi Menggunakan Metode Variable Costing, dengan menggunakan Visual Basic 6.0 sebagai bahasa program dan MySQL sebagai database. Hasil dari aplikasi ini yaitu pencatatan seluruh data yang berkaitan dengan proses perhitungan Harga pokok Produksi secara terkomputerisasi. Hasil dari aplikasi ini dapat mempermudah proses penghitungan harga pokok produksi, mempermudah dalam pengelompokan data produksi dan dengan adanya metode variable costing pada sistem ini menjadikan penghitungan harga pokok produksi menjadi lebih sesuai dengan biaya yang dikeluarkan.
\end{abstract}

Kata kunci : Sistem Informasi Akuntansi, Harga Pokok Produksi, Variable Costing

\begin{abstract}
Muzammil Convection is one of the UKM engaged in the production of jeans, which is located in the village of Cepoko Mulyo-Kendal, Central Java which was founded in 1998. The calculation of production costs and selling price of the Muzammil Cepoko Mulyo Convection still uses conventional calculations. In fact, the current era requires better strategic management in order to compete competitively in the industrial world. Therefore we need an appropriate information system to support the business activities of the Muzammil Convection in conducting cost grouping, data and making a reporting system. One thing that can be done is to build an information technology-based information system to facilitate the process of calculating production costs and increase the accuracy of overall financial management. This study designed an accounting information system for calculating the cost of production using the variable costing method, using Visual Basic 6.0 as the programming language and MySQL as the database. The result of this application is the recording of all data related to the computerized calculation of the Cost of Production. The results of this application can simplify the process of calculating the cost of goods manufactured, facilitate the grouping of production data and the existence of the variable costing method in this system makes the calculation of the cost of goods manufactured more in accordance with the costs incurred.
\end{abstract}

Keywords: Accounting Information Systems, Cost of Production, Variable Costing

\section{Pendahuluan}

Dewasa ini perkembangan perekonomian di Indonesia dapat mendorong persaingan antar perusahaan. Dengan kondisi itu, para pemilik perusahaan berlomba-lomba berinovasi untuk bisa bersaing dan terus berkembang. Salah satunya adalah di bidang teknologi informasi, karena inilah yang sangat berperan dalam memajukan perusahaan.

Sistem informasi adalah suatu rangkaian formal yang dimulai dari pengumpulan data, pemrosesan data menjadi sebuah informasi dan 
proses pendistribusian informasi tersebut kepada pengguna. Sistem Informasi secara garis besar menerima input yaitu transaksi, kemudian melalui sebuah proses sehingga input tersebut dapat terkonversi menjadi informasi output. Dan output akhir ini yang dapat diakses oleh pengguna (Mahatmyo, 2014).

Usaha Kecil Menengah (UKM) atau bisa juga disebut dengan perusahaan merupakan suatu organisasi yang tersusun dengan baik dan mempunyai visi misi atau tujuan, tujuan bisa dengan jangka pendek ataupun jangka panjang. Perusahaan didirikan tentunya bertujuan untuk menghasilkan laba atau keuntungan dari proses produksi yang dijalankan. Hal ini menjadi penting karena pendapatan atau laba berkaitan langsung dengan keseimbangan perusahaan, antara biaya produksi, proses dan hasil produksinya. Biaya produksi disebut juga sebagai pokok dari produksi dan menjadi faktor utama dalam menentukan harga jual dari sebuah produk. Dengan demikian biaya produksi sangat berpengaruh pada keberhasilan suatu perusahaan.

Variable costing adalah sebuah metode penentuan harga pokok produksi dengan cara memperhitungkan biaya produksi berdasarkan variabel harga pokok produksi. Penentuan variable costing terdiri dari beberapa unsur, yaitu biaya bahan baku, biaya produksi atau biaya tenaga kerja dan juga biaya overhead (Mulyadi, 2015:18). Elemen harga pokok produk pada variable costing dipengaruhi oleh biaya-biaya produksi yang berubah-ubah berdasarkan perubahan output yang dihasilkan.

Konveksi Bapak Muzammil adalah salah satu UKM yang bergerak dibidang produsen celana jeans, yang berlokasi di desa Cepoko Mulyo-Kendal, Jawa Tengah yang didirikan sejak tahun 1998. Konveksi Muzammil memiliki 50 mesin dan memiliki kurang lebih 40 orang karyawan. Dengan jumlah produksi mencapai kurang lebih 4000 pcs per minggu saat ramai dan kurang lebih 2000 pcs per minggu saat sepi. Konveksi Muzammil Cepoko Mulyo masih menggunakan perhitungan secara konvensional dalam menjalankan proses bisnisnya, terutama pada perhitungan biaya produksi dan harga jual produk. Hal ini menjadi riskan dikarenakan untuk tetap berasing di lingkungan industri diperlukan manajemen strategi yang lebih baik.

Agar dapat mendukung proses bisnis yang telah berjalan pada Konveksi Bapak Muzammil maka diperlukan sebuah sistem informasi yang sesuai. Salah satu yang dapat dijadikan opsi adalah sistem informasi yang berbasis teknologi informasi sehingga bisa terintegrasi. Sistem informasi ini diharapkan dapat membantu UKM Konveksi Muzammil dalam melakukan pengelompokkan biaya, pengaturan data dan pembuatan laporan.
Sistem informasi ini juga diharapkan dapat memberi kemudahan serta meningkatkan akurasi perusahaan dalam proses penghitungan biaya produksi. Oleh karena itu diangkat penelitian dengan judul "Sistem Informasi Akuntansi Perhitungan Harga Pokok Produksi Menggunakan Metode Variable Costing Pada Konveksi Muzammil”.

\section{Metode Penelitian}

Metode penelitian Research \& Development digunakan penulis dalam penelitian ini. Metode ini biasa disebut dengan metode pengembangan. Metode ini dapat menghasilkan sebuah produk dalam bentuk prototype yang merupakan pengembangan dari system prototyping.

Dalam hal ini penulis melakukan 6 tahapan dalam metode penelitian dan pengembangan (Research \& Development) dari 10 tahapan yang disarankan, yaitu :

1) Potensi dan Masalah

Setiap penelitian pasti berawal dari adanya sebuah masalah. Dari masalah tersebut akan diambil sebuah potensi yang akan diberdayakan sehingga bisa menghasilkan nilai tambah.

2) Mengumpulkan Informasi

Langkah selanjutnya adalah mengumpulkan berbagai informasi terkait berdasarkan potensi dan masalah yang sudah ditemukan. Informasi ini bersifat factual dan up to date sehingga diharapakan bahan atau informasi ini bisa menjadi salah satu penunjang untuk mengatasi masalah tersebut di atas.

3) Desain Produk

Pada tahap ini penulis membuat rancangan kerja baru yang dibuat berdasarkan hasil penilaian dari proses system kerja yang sudah berjalan. Supaya pada akhir penelitian dapat menemukan atau menghasilkan sistem kerja baru yang lebih tepat dan menjadi jawaban dari permasalah sebelumnya tersebut.

4) Validasi Desain

Proses validasi desain menjadi sangat penting dikeranakan dalam tahap ini dilakukan penilian terhadp system kerja baru dibandingkan dengan system kerja yang lama. Apakah system kerja yang beru tersebut menjadi lebih efektif ataukan sebaliknya.

5) Revisi Desain

Setelah melewati proses validasi desain dan ternyata masih ditemukan kelemahankelamahan dalam system, maka pada tahap ini dilakukan proses revisi desain. Proses ini bertujuan untuk mengurangi kelemahan dari sistem dan untuk disempurnakan menjadi lebih baik. 
Jurnal Teknologi Informasi dan Komunikasi, ISSN : 2087-0868, Volume 11, Nomor 2, September 2020, Perancangan Sistem Informasi Akuntansi Perhitungan Harga Pokok Produksi Konveksi Muzammil Kendal Menggunakan Metode Variable Costing .

6) Uji Coba Produk

Sebelum digunakan di lapangan, sistem yang baru perlu dilakukan uji coba terlebih dahulu. Tujuan uji coba yaitu membandingkan tingkat efektifias dan efisiensi dari sistem yang baru terhadap sistem yang lama. Dalam proses ini dapat dilihat apakah sistem tersebut layak digunakan ataukan perlu adanya revisi kembali.

\subsection{Metode Pengumpulan Data}

Dalam pengumpulan data penelitian, penulis menggunakan metode pengumpulan data, yaitu dengan perincian sebagai berikut:

1) Metode Observasi, yaitu proses mengamati yang dilakukan secara sistematis terhadap proses sistem perusahaan kemudian dilakukan pencatatan sehingga dapat ditemukan data-data penunjang untuk proses perancangan sistem yang baru.

2) Metode Kepustakaan, yaitu dengan memperluas cakrawala pandang dengan cara mencari literatur yang sesuai dengan alur penelitian. Dalam hal ini penulis mengacu pada buku, jurnal penelitian sejenis, diktat maupun catatan-catatan yang bisa menunjang keberhasilan dari penelitian ini.

3) Metode Wawancara, ini dilakukan agar penulis bisa memperoleh informasi maupun masukanmasukan secara langsung oleh pemilik perusahaan. Dalam hal ini penulis melakukan wawancara kepada direktur dan admin konveksi Muzammil.

\subsection{Kerangka Berfikir}

Dalam proses pembuatan Sistem Informasi Akuntansi Perhitungan Harga Pokok Produksi Konveksi Muzammil Kendal Menggunakan Metode Variable Costing penulis menggunakan kerangka pemikiran berikut sebagai dasar pembuatannya.

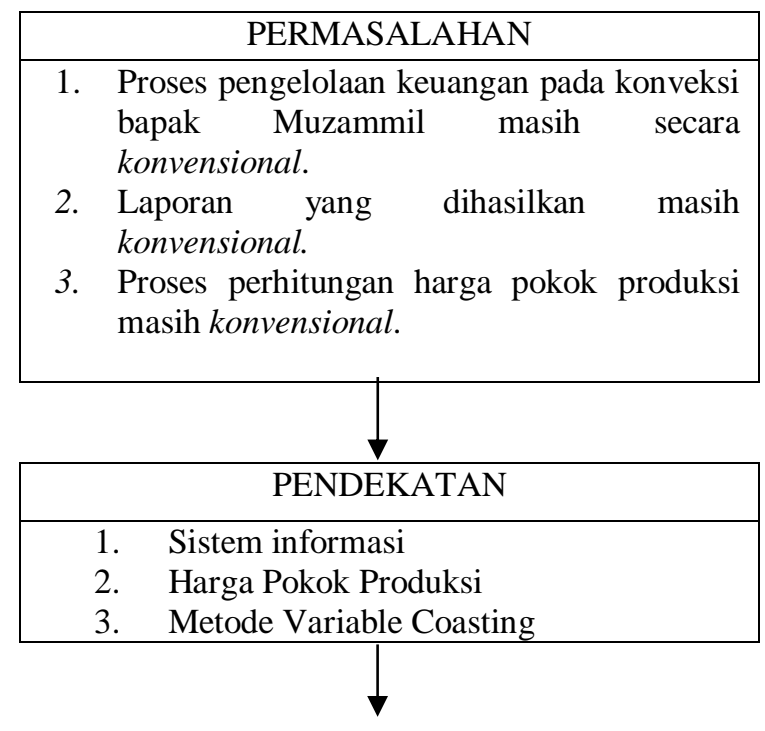

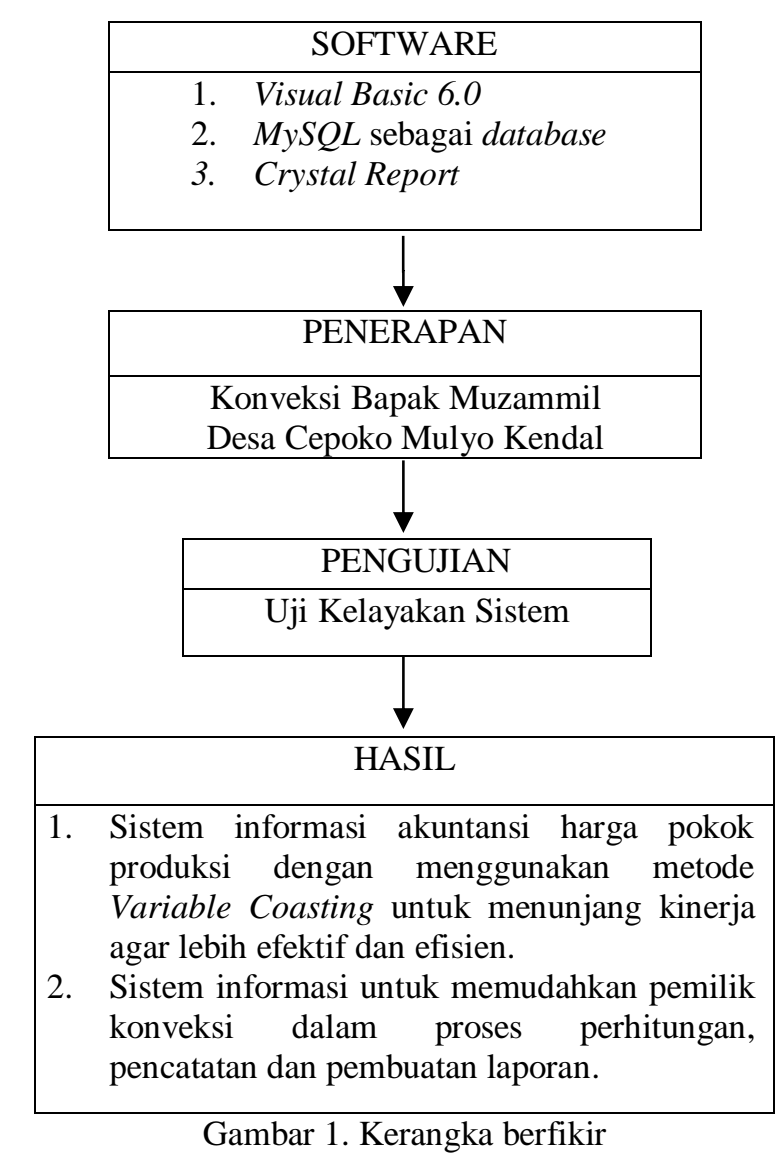

\subsection{Diagram Alir}

Metode Prototype dibuat dengan tujuan agar bisa menerima perubahan-perubahan untuk menyempurnakan Prototype yang sudah ada sehingga dalam prosesnya bisa menghasilkan sebuah sistem informasi yang sesuai dengan kondisi perusahaan. Diharapkan sistem yang baru dapat diterima dan perubahan-perubahan yang terjadi dianggap merupakan sebagai dari proses pengembangan itu sendiri. Tahapan-tahapan dalam proses pengembangan Prototype dapat dilihat pada diagram alir dibawah ini (Pengantar Sistem Informasi, Yakub, 2012)

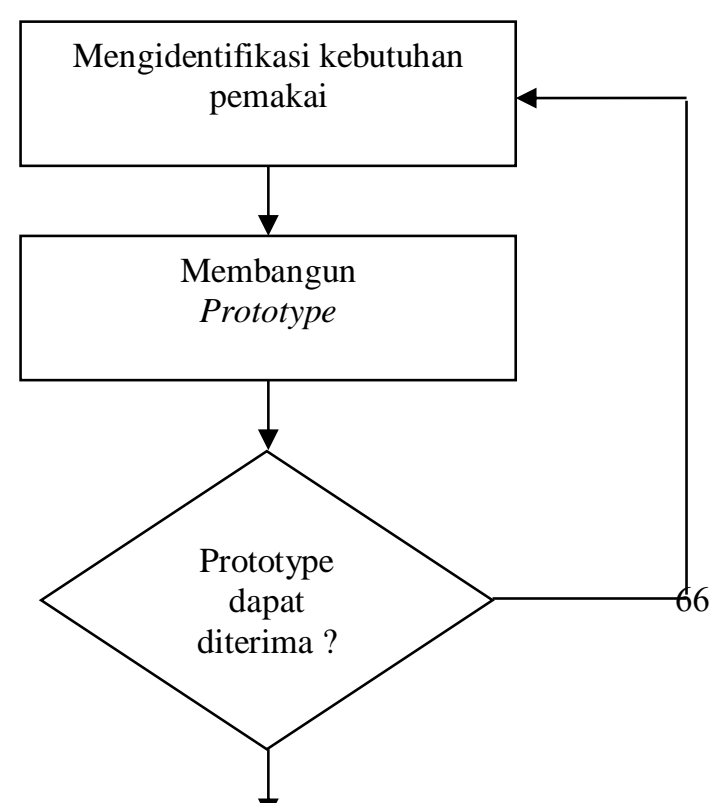


Gambar 2 Diagram alir metode Pengembangan Sistem Prototyping

\subsection{Teknik Pengolahan Data}

Teknik pengolahan data merupakan sebuah teknik yang bertujuan untuk mengolah data yang sudah terkumpul pada awal penelitian. Hasil akhir dari pengolahan data akan mendapatkan suatu kesimpulan yang digunakan sebagai tolak ukur keberhasilan penelitian.

Pada penelitian ini penulis menentukan terlebih dahulu skala pengukurannya yang dijadikan acuan untuk menentukan nilai interval atau panjang pendeknya interval yang digunakan dalam pengukuran. Dengan adanya nilai pengukuran yang tepat maka diharapkan akan mendapatkan hasil yang maksimal. Interval pengukuran ini sendiri diambil berdasarkan kesepakatan sehingga akan mendapakan hasil secara kuantitatif. Dalam penelitian ini, penulis menggunakan skala Likert untuk proses penghitungan datanya. Skala Likert sangat cocok digunakan dalam proses mengukur sikap, pendapat dan persepsi sekelompok orang maupun individu terhadap sebuah variabel penelitian. (Sugiyono, 2014).

Skala likert ini akan digunakan sebagai variable pengukuran yang dijabarkan sebagai indikator variabel. Kemudian indikator tersebut bisa menjadi tolak ukur dalam penyusunan bagian-bagian yang dapat disusun sebagai pernyataan ataupun pertanyaan.

\section{Hasil dan Pembahasan}

\subsection{Hasil Penelitian}

Berdasarkan hasil Analisis dan pengamatan yang penulis lakukan pada konveksi muzammil dalam penentuan harga pokok produksi, penulis melakukan evaluasi sistem yang sedang berjalan. Sistem Informasi Perhitungan Harga Pokok Produksi Pada Konveksi Muzammil yang berjalan saat ini adalah :

1) Pencatatan orderan dan perhitungan harga pokok produksi pada konveksi muzammil masih menggunakan sistem manual yaitu dengan mencatat pada buku laporan.
2) Proses kebutuhan yang diperlukan untuk produksi di catat dalam buku transaksi yang memungkinkan untuk hilang atau rusak.

3) Terbatasnya sistem informasi penentuan harga pokok produksi sehingga dalam penyajian laporan harga pokok produksi membutuhkan waktu lama karena setitiap orderan harus dihitung manual untuk menentukan harga pokok produksinya.

Oleh karena itu diperlukan suatu sistem yang dapat meminimalkan hal-hal tersebut diatas, sehingga proses produksi dapat terdata secara cepat dan laporan-laporan yang di peroleh semakin akurat dan aman karena tersimpan didalam sistem.

Solusi yang diusulkan penulis dalam penyelesaian permasalahan yang ada pada sistem perhitungan harga pokok produksi pada konveksi muzammil adalah membuat sistem informasi yang dapat menyimpan data produksi yang aman dan dapat digunakan sebagai arsip data perusahaan, sehingga dapat mempermudah aktifitas produksi, membuat laporan produksi untuk mempermudah menyajikan laporan perhitungan harga pokok produksi.

\subsection{Hasil Pengembangan}

Identifikasi sistem informasi dilakukan dengan analisa dan perancangan sistem terlebih dahulu. Model pengembangan sistem ini mampu menggambarkan keadaan sebenarnya dari sistem yang dirancang. Beberapa model pengembangan tersebut antara lain :

1) Identifikasi sistem

Yaitu proses identifikasi berupa sistem informasi perhitungan harga pokok pada proses produksi konveksi Muzammil

2) Identifikasi data

Data yang diidentifikasi yaitu data pesanan barang dan data variabel biaya

3) Identifikasi informasi

Informasi yang diidentifikasi berkaitan dengan laporan pesanan, laporan harga pokok produksi dan laporan harga pokok penjualan.

Untuk menunjang keberhasilan sistem yang baru maka dibutuhkan software dan hardware pendukung. Software yang dibutuhkan yaitu sistem operasi Windows 7 ke atas, server side menggunakan XAMPP dan VB 6.0 sebagai alat bantu pembuatan sistem. Hardware atau perangkat keras yang dibutuhkan adalah komputer atau laptop dengan spesifikasi processor Core i3 ke atas, hardisk 500 GB, Ram 2 Gb dan VGA 64 Mb.

Sumbar daya manusia juga sangat dibutuhkan dalam pengembangan sistem. Diperlukan user atau operator yang terdidik dan terlatih sehingga dapat mengoperasikan aplikasi atau sistem yang baru secara maksimal. 
Jurnal Teknologi Informasi dan Komunikasi, ISSN : 2087-0868, Volume 11, Nomor 2, September 2020, Perancangan Sistem Informasi Akuntansi Perhitungan Harga Pokok Produksi Konveksi Muzammil Kendal Menggunakan Metode Variable Costing .

\subsection{Pembahasan Produk Akhir}

Dalam bagian ini akan dipaparkan secara lengkap untuk memberikan gambaran dan karakteristik produk sistem informasi yang merupakan produk akhir dari kegiatan penelitian ini. Adapun perinciannya adalah sebagai berikut :

1) Halaman Login

Halaman ini berfungsi untuk pengamanan aplikasi dengan memasukkan ID pengguna dan sandi yang sesuai.

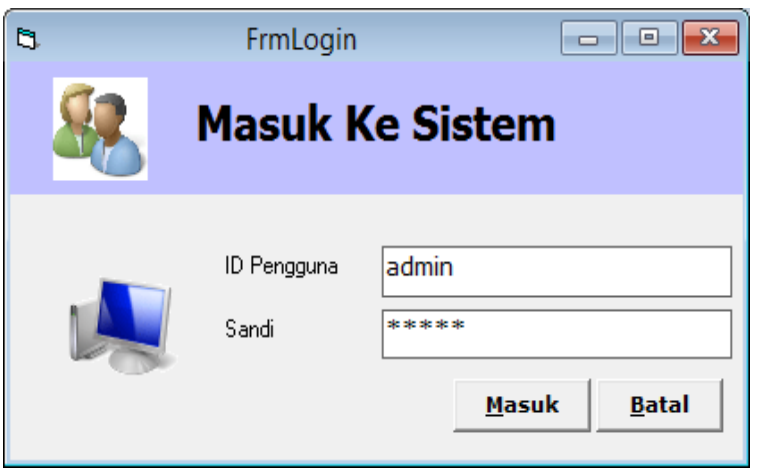

Gambar 3. Halaman Login

\section{2) Halaman Menu}

Halaman ini akan tampil jika proses masuk sistem berhasil dilakukan. Fungsi halaman ini sebagai panel Sistem Informasi Perhitungan Harga Pokok Produksi Menggunakan Metode Variable Costing Pada UKM Konveksi Muzammil.

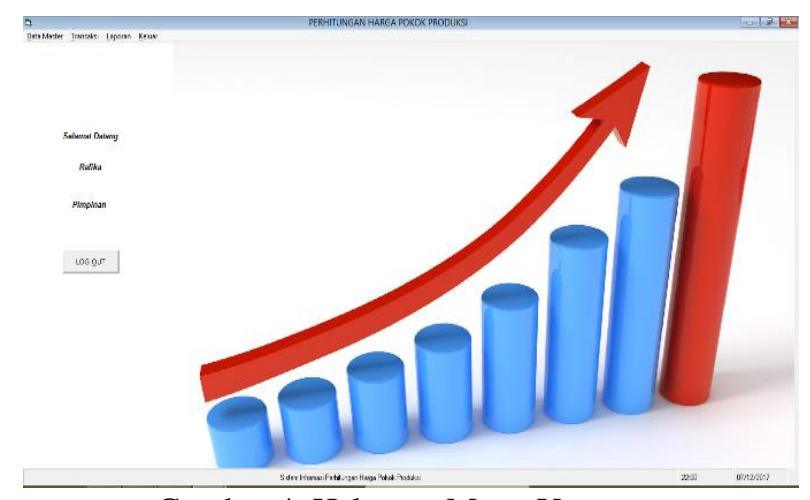

Gambar 4. Halaman Menu Utama

3) Form Data Pemakai

Halaman ini berfungsi untuk memasukkan data pengguna sistem

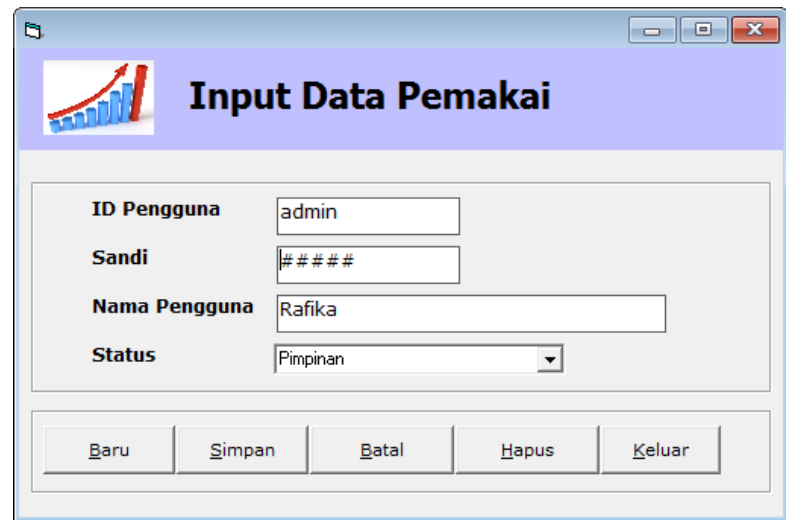

Gambar 5. Halaman Form Pemakai

Keterangan:

a. Klik Tombol Baru untuk memulai memasukan data pemakai.

b. Masukan ID Pengguna, Sandi, Nama, dan Status.

c. Tombol Simpan digunakan untuk menyimpan data pemakai.

d. Tombol Batal digunakan untuk membatalkan pengisian data.

e. Tombol Hapus, untuk menghapus data.

f. Tombol Keluar, untuk keluar dari jendela form pemakai.

4) Halaman Data Pelanggan

Halaman ini digunakan untuk input data pelanggan

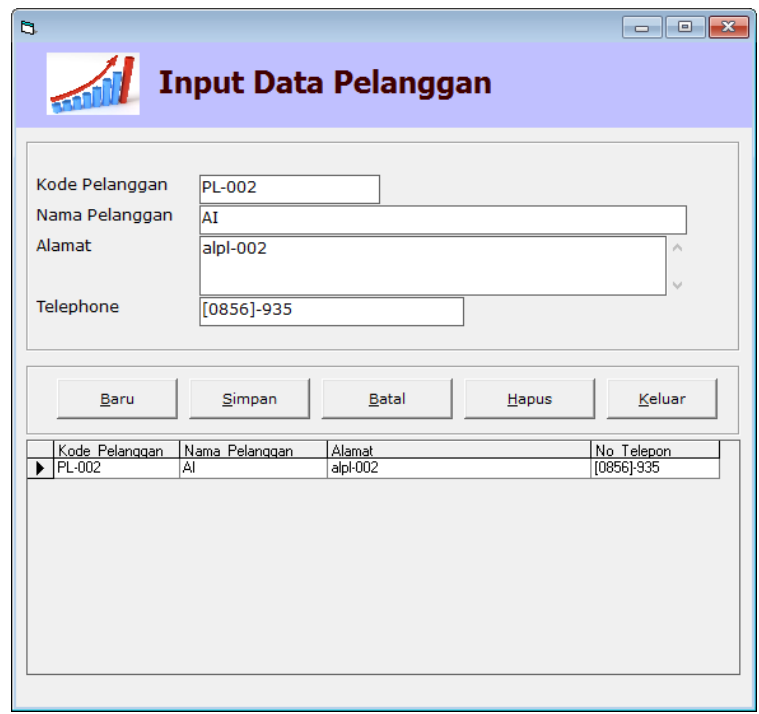

Gambar 6. Halaman Form Data Pelanggan

Keterangan :

a. Klik Tombol Baru untuk memulai memasukan data pelanggan.

b. Masukan kode pelanggan, nama pelanggan, alamat dan telepon. 
Jurnal Teknologi Informasi dan Komunikasi, ISSN : 2087-0868, Volume 11, Nomor 2, September 2020, Perancangan Sistem Informasi Akuntansi Perhitungan Harga Pokok Produksi Konveksi Muzammil Kendal Menggunakan Metode Variable Costing .

c. Tombol Simpan pada sistem digunakan untuk menyimpan data pelanggan.

d. Tombol Batal pada sistem digunakan untuk membatalkan data yang akan disimpan.

e. Tombol Hapus pada sistem digunakan untuk menghapus data

f. Tombol Keluar, untuk keluar dari jendela form pelanggan

5) Halaman Data Pesanan

Halaman ini digunakan untuk input data pesanan.

Keterangan :

a. Klik Tombol Baru untuk memulai memasukan data pesanan.

b. Masukan kode pesanan, nama pesanan, pelanggan, jumlah, tanggal pesan, tanggal kirim dan spesifikasi.

c. Tombol Simpan untuk menyimpan data pesanan.

d. Tombol Batal digunakan untuk membatalkan data yang akan disimpan.

e. Tombol Hapus, untuk menghapus data

f. Tombol Keluar, untuk keluar dari jendela form pesanan

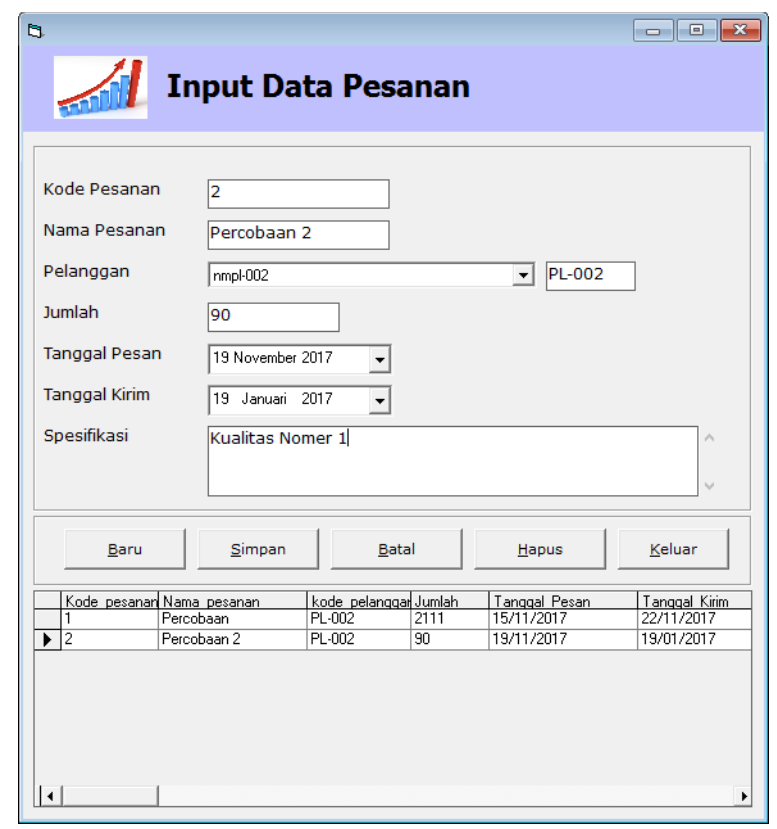

Gambar 7. Halaman Form Data Pesanan

6) Halaman Data Input Biaya Variabel

Halaman ini digunakan untuk menginput biaya variable tiap pesanan

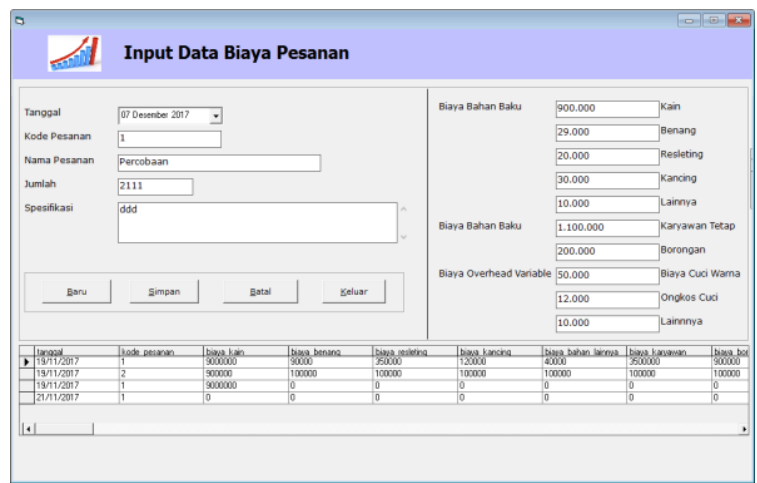

Gambar 8. Halaman Form Input Biaya Pesanan

Keterangan :

a. Klik Tombol Baru untuk memulai memasukan biaya.

b. Masukan tanggal, kode pesanan, biaya kain, biaya benang, biaya releting, biaya kancing, dll.

c. Tombol Simpan digunakan untuk menyimpan data biaya pesanan.

d. Tombol Batal digunakan untuk membatalkan data yang akan disimpan.

e. Tombol Hapus digunakan untuk menghapus data

f. Tombol Keluar ketika di klik makan otomatis dari jendela form pesanan.

7) Laporan Data Pelanggan

Halaman ini digunakan untuk melihat laporan pelanggan konveksi Muzammil.

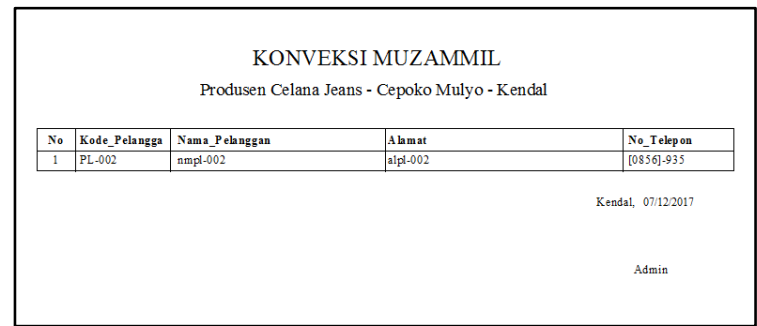

Gambar 9. Halaman Laporan Data Pelanggan

8) Laporan Data Pesanan

Halaman ini digunakan untuk melihat laporan pesanan konveksi Muzammil

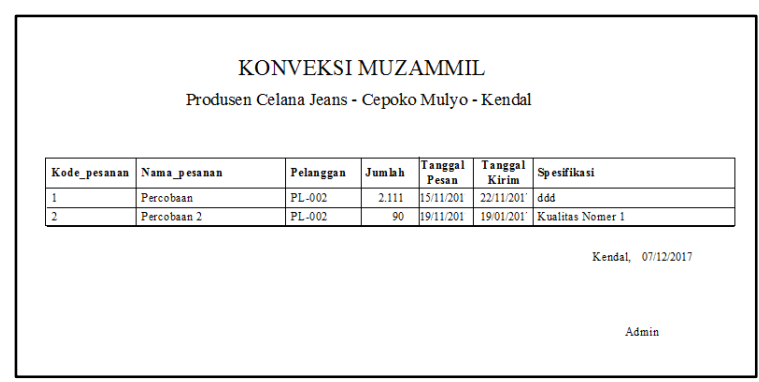

Gambar 10. Halaman Laporan Data Pesanan 
Jurnal Teknologi Informasi dan Komunikasi, ISSN : 2087-0868, Volume 11, Nomor 2, September 2020, Perancangan Sistem Informasi Akuntansi Perhitungan Harga Pokok Produksi Konveksi Muzammil Kendal Menggunakan Metode Variable Costing .

9) Laporan Data Harga Pokok Produksi Halaman ini digunakan untuk melihat laporan harga produksi konveksi Muzammil

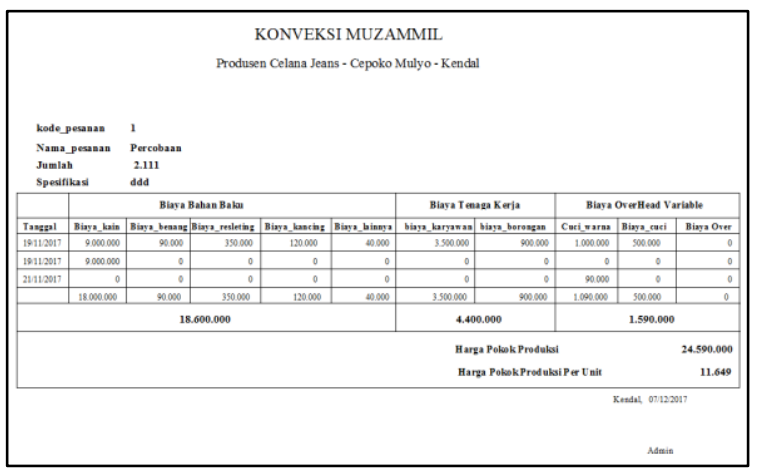

Gambar 11. Halaman Laporan Data Pokok Produksi

10) Laporan Data Harga Pokok Penjualan Halaman ini digunakan untuk melihat laporan harga pokok penjualan konveksi Muzammil.

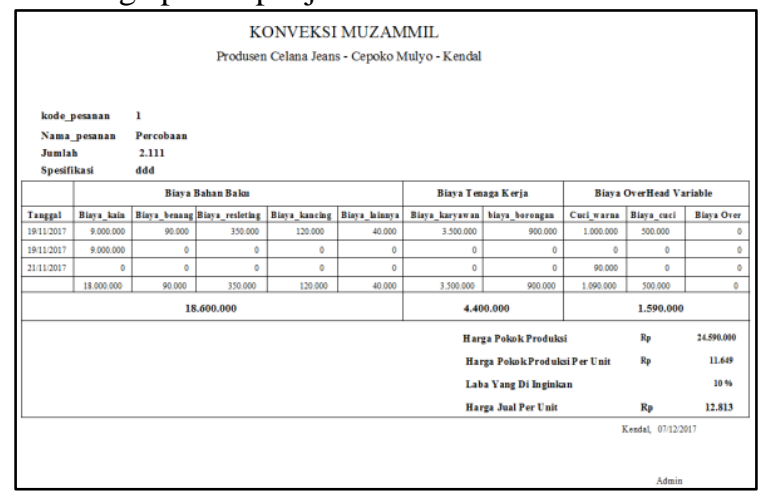

Gambar 12. Halaman Laporan Data Pokok Penjualan

\section{Kesimpulan}

Berdasarkan hasil penelitian ini dan berdasarkan hasil akhir yang didapatkan berupa Sistem informasi perhitungan harga pokok produksi menggunakan metode variable costing maka dapat penulis simpulkan bahwa :

1) Sistem yang baru ini dapat mempermudah proses penghitungan harga pokok produksi pada konveksi Muzammil

2) Dengan adanya sistem ini dapat mempermudah dalam pengelompokan data produksi konveksi Muzammil

3) Metode variable costing pada sistem ini terbukti menjadikan penghitungan harga pokok produksi menjadi lebih sesuai dengan biaya yang dikeluarkan.

Adapun beberapa saran terkait penelitian ini supaya terjadi peningkatan kinerja sistem, antara lain:

1) Sistem yang baru agar bisa berjalan dengan baik, maka diperlukan adanya pelatihan bagi karyawan konveksi muzammil tentang sistem dan tata cara penggunaan program aplikasi yang akan dipakai ini.

2) Sebaiknya ke depan, dilakukan pengembangan sistem agar sistem informasi ini lebih efektif lagi.

\section{Daftar Pustaka :}

Mahatmyo, Atyanto. (2014). Sistem Informasi Akuntansi Suatu Pengantar Yogyakarta: Deepublish.

Mulyadi. (2015). Akuntansi Biaya. Yogyakarta : Unit Penerbit dan Percetakan Sekolah Tinggi Ilmu Manajemen YKPN

Muslihudin, Muhamad., Oktafianto. (2016). Analisis dan Perancangan Sistem Informasi Menggunakan Model Terstruktur dan UML. Yogyakarta : ANDI

Nurajizah, S. (2015). Sistem Informasi Perpustakaan Berbasis web dengan Metode Prototype : studi kasus sekolah Islam gema Nurani Bekasi. Seminar nasional Inovasi dan tren (SNIT)

Oentoe, C. (2013). Analisis perhitungan Biaya Produksi Menggunakan Metode Variabel Costing. Jurnal EMBA, 599-605.

Putra, H. S., \& Wahyu, A. W. (2014). Perancangan Aplikasi Penentuan Harga Pokok Produksi Produk Turunan tape Singkong Dalam Usaha Mencapai Harga Kompetitif. Jurnal Akuntansi Universitas Jember , 17-31

Rusdiana, H.a., Irfan, Moch. (204). Sistem Informasi Manajemen. Bandung : Pustaka Setia

Sitorus, Lamhot. (2015). Algoritma dan Pemrograman . Yogyakarta : ANDI

Sugiyono. (2016). Metode Penelitian Pendidikan (Pendekatan Kuantitatif, Kualitatif, dan R\&D). Bandung : Alfabeta

Sukamto, R.A., Shalahuddin, M. (2016). Rekayasa Perangkat Lunak. Bandung : Informatika.

Sutabri, Tata. (2014). Sistem Informasi Manajemen (Edisi Revisi). Yogyakarta : ANDI 